\title{
Evolutionary Developmental Biology (Evo-Devo): Past, Present, and Future
}

\author{
Brian K. Hall
}

Published online: 8 June 2012

(C) Springer Science+Business Media, LLC 2012

\begin{abstract}
Evolutionary developmental biology (evo-devo) is that part of biology concerned with how changes in embryonic development during single generations relate to the evolutionary changes that occur between generations. Charles Darwin argued for the importance of development (embryology) in understanding evolution. After the discovery in 1900 of Mendel's research on genetics, however, any relationship between development and evolution was either regarded as unimportant for understanding the process(es) of evolution or as a black box into which it was hard to see. Research over the past two decades has opened that black box, revealing how studies in evo-devo highlight the mechanisms that link genes (the genotype) with structures (the phenotype). This is vitally important because genes do not make structures. Developmental processes make structures using road maps provided by genes, but using many other signals as well-physical forces such as mechanical stimulation, temperature of the environment, and interaction with chemical products produced by other species-often species in entirely different kingdoms as in interactions between bacteria and squid or between leaves and larvae (Greene Science 243:643-666, 1989). Not only do genes not make structures (the phenotype), but new properties and mechanisms emerge during embryonic development: genes are regulated differentially in different cells and places; aggregations of similar cells provide the cellular resources (modules) from which tissues and organs arise; modules and populations of differently differentiated cells interact to set development along particular tracks; and organisms interact with their environment and create their niche in that
\end{abstract}

B. K. Hall $(\bowtie)$

Department of Biology, Dalhousie University,

Halifax, NS, Canada B3H 4R2

e-mail: bkh@dal.ca environment. Such interactions are often termed "epigenetic," meaning that they direct gene activity using mechanisms that are not encoded in the DNA of the genes. This paper reviews the origins of evo-devo, how the field has changed over the past 30 years, evaluates the recognition of the importance for development and evolution of mechanisms that are not encoded in DNA, and evaluates what the future might bring for evo-devo. Although impossible to know, history tells us that we might expect more of the same; expansion of evo-devo into other areas of biology (ecology, physiology, behavior); absorption of evo-devo by evolution or a unification of biology in which evo-devo plays a major role.

Keywords Evolutionary developmental biology $\cdot$ Evodevo $\cdot$ Modules $\cdot$ Gene regulation $\cdot$ Evolutionary developmental mechanisms $\cdot$ Modern synthesis $\cdot$ Expanded modern synthesis

\section{Introduction}

Evolutionary developmental biology (evo-devo) is the name for that part of biology involved in understanding how alterations in the mechanisms of embryonic development influence or direct evolutionary changes in any and all stages of the life cycle. The field has become enormous in recent years; McCain (2009) analyzed thousands of papers published between 1975 and 2004 in her study of the impact of one early practitioner of evo-devo, Con$\mathrm{rad} \mathrm{Hal}$ Waddington. Consequently, what follows is my perspective on the past, present, and future of evo-devo. I apologize in advance to those researchers whose contributions are underrepresented. 
Although not usually regarded as a "founding father" of the field, the term "evolutionary developmental biology" appears first to have been used in print in 1983 by the zoologist and later environmentalist, Peter Calow, of the University of Sheffield in England. In an earlier book, Calow (1978) had provided an influential treatment of life cycles from developmental, evolutionary, and physiological points of view. Calow included a chapter on evolution and development (in itself unusual at the time ${ }^{1}$ ) in his 1983 book Evolutionary Principles, published by Blackie in their Tertiary Level Biology Series. Calow described the field of evolution and development as "evolutionary developmental biology," noting that "The area is a relatively new and complex one so the reader should not expect to find fully comprehensive treatments in the literature" (p. 80).

In his book of only 100 pages and 105 references and contrary to much prior opinion, Calow emphasized that natural selection could and did act at any stage in the life cycle of multicellular organisms, a conclusion reached by one of the founders of evolutionary embryology 109 years earlier. In his first paper on shark development, Francis Balfour argued for the role of selection in embryonic development as perhaps even more relevant for evolution than selection on the adult:

I see no reason for doubting that the embryo in the earliest periods of development is as subject to the laws of natural selection as is the animal at any other period. Indeed, there appear to me grounds for the thinking that it is more so. (Balfour 1874, p. 343)

Although the roots of evo-devo are deep (Gould 1977; Bonner 1982; Arthur 1988; Hall and Olson 2003; Laubichler and Maienschein 2007; Olsson et al. 2009), evo-devo is just coming into its own. In the introduction to the publication of the Kowalevsky Medal winner symposium held in January 2003 (published in 2004) to recognize the research of the first recipients of the Kowalevsky medal, Laubichler and Wagner concluded that 'By all accounts 'evo-devo' has arrived. It is now solidly entrenched in the conceptual framework of modern biology and has all the markings of a new discipline, such as representation in professional societies, scientific journals devoted to the field, academic programs and job searches, panels at funding agencies, textbooks, etc." (2004, p. 1) Eight years later, classes, courses, workshops, postdoctoral fellowships, faculty positions,

\footnotetext{
${ }^{1}$ As an exception, one of the acknowledged founders of evo-devo, N.J. Berrill (1903-1996), included a chapter on evolution and development in an undergraduate biology textbook (Berrill 1966) in which he saw the importance of development for understanding phylogenetic relationships, not because of recapitulation (see Origins of Evo-Devo) but because of developmental mechanisms such as neoteny.
}

university chairs, and research grant selection panels in evo-devo are widespread.

I took "evolutionary developmental biology" as the title for my 1992 book (Hall 1992), which set out to summarize what was then known about the origins of the field, its history, and its role in contributing to the evolutionary process. I will do a little of the same in the paper. Why? Because we can only appreciate the future prospects of evodevo in the context of its past. What questions were being asked of embryos and of development? To which organisms were these questions addressed? Were we seeking a broad overarching theory of evo-devo that would apply to all animal life or differences that characterized grades of biological organization - kingdoms, phyla, classes, even individual species. What was missing from prevalent approaches to evolution that necessitated this new developmental approach?

\section{Origins of Evo-Devo}

I go back to the late nineteenth century when we find the origins of evo-devo in the research of individuals in England (largely Trinity College, Cambridge) and in Continental Europe. These evolutionary morphologists/evolutionary embryologists were attracted to this research following the publications of The Origin of Species by Charles Darwin (Darwin 1859) and Ernst Haeckel's theory that ontogeny recapitulates phylogeny (Haeckel 1866). Paradoxically, the first published study testing Darwin's theory using embryos and larvae-Fritz Müller's study of crustacean life histories (Müller 1864) - showed that ontogeny could be used to understand patterns of evolutionary history (phylogeny) and that mechanisms could be sought in ontogeny. So varied were crustacean life history strategies found to be that Müller found he could use the details and varieties of life history stages to construct a phylogeny of crustacean relationships. Haeckel took exactly the opposite position. Haeckel theorized that phylogeny explains ontogeny and erected his Biogenetic Law on this basis.

Embryos provided the way to study evolution. The fossil record was incomplete. Embryos, on the other hand, recorded in their development the history of their ancestors. This history had to be read with great care; there were gaps in the record, and secondary specializations such as the placenta could confuse the unwary (Bowler 1996; Hall 1999). Nevertheless, from the late 1860 s or early 1870 s until the mid-1880s, evolutionary embryology was the field that attracted the brightest and best zoologists. It attracted those who wanted to study embryos in the laboratory or field station and those who wanted to seek embryos of such 'missing links' as the platypus (thought to link reptiles and mammals), lungfish (thought to link fish and tetrapods), and 
the velvet worm Peripatus (thought to link insects and arthropods) in such exotic places as Australia, South America and Africa (Hall 1999, 2001; MacLeod 1994; Bowler 1996; Laubichler and Maienschein 2007). William Bateson, the English zoologist who coined the name "genetics," began his career as an evolutionary embryologist. Reminiscing on his career, Bateson commented that

Morphology was studied because it was the material believed to be the most favorable for the elucidation of the problems of evolution, and we all thought that in embryology the quintessence of morphological truth was most palpably presented. Therefore every aspiring zoologist was an embryologist, and the one topic of professional conversation was evolution. (Bateson 1922, p. 56)

Frustration with reconstructing evolutionary trees from embryonic sequences, the rise of experimental and physiological approaches to embryonic development in the 1880s, and the rediscovery of Mendelian genetics in 1900 all cast evolutionary embryology into a backwater from which it would take a century to resurface. Mendel's principles of segregation and assortment coupled with studies on the fruit fly Drosophila provided a powerful foundation upon which the new science of genetics was built. Publication of Dobzhansky's (1937) influential book, "Genetics and the Origin of Species," provided a basis for understanding evolution through population genetics, the mathematical models for which have been developed in the 1920 .

By the middle of the twentieth century, maintenance of the features of organisms, variation in those features, and the origin of new features all seemed explicable by a fusion of Mendelian and population genetics. Paradoxically, the use of Drosophila as the model organism for genetics eliminated the roles of embryonic development and of the environment from evolutionary discussion and theory; inbred laboratory organisms display none of the variation and adaptability seen in nature.

\section{The Twentieth Century}

Despite the valiant attempts of a handful of individual researchers through the first six decades of the twentieth century, linking embryos and evolution did not make a comeback until Stephen J. Gould's book Ontogeny and Phylogeny was published in 1977. Weighing in at 501 pages, this was no easy read, especially as the first half was a detailed history of the way in which development and evolution (ontogeny and phylogeny-the terms proposed by Haeckel) had been related in the past and when the past for Gould began at $450 \mathrm{BC}$. This historical tour de force was important; Gould reminded us, for indeed we had forgotten that we had been seeking relationships between development and evolution for millennia.

The second half of Gould's book was equally important because it revisited a concept conceived by Haeckel in the 1860 s, elaborated by Gavin de Beer in the 1930s (de Beer 1930), but then all but abandoned. Haeckel and de Beer's concept is summed up in the word "heterochrony"changes in the timing of developmental processes between a descendant and its ancestors (see Zelditch 2001; Willmore 2010). De Beer's insight was to take studies showing that genes affected the rates of physiological processes in insects (Goldschmidt 1918) and to see that the rates of development must change during evolution. Here was a way in which comparative embryology could be investigated in an evolutionary (phylogenetic) framework). Heterochrony as a developmental mechanism operating during individual development could be selected for and so was important in evolutionary change; heterochrony was an "evolutionary developmental mechanism" (Hall and Olson 2003).

Julian Huxley, one of the founders of the modern synthesis of evolution, appreciated the importance for evolution of the study of genes in development - "a study of genes during development is as essential for an understanding of evolution as are the study of mutation and selection" (Huxley 1942, p. 8) - but even Huxley neglected to incorporate development into evolutionary theory. Other founders of the modern synthesis such as Ernst Mayr spoke of an internal biology (to which development belonged) and an external biology (evolution, ecological interactions) as if the two were separate and non-overlapping/interacting one to the other (Mayr 1982, 1997).

Because it was difficult to compare ancestors and their descendants, living organisms were compared with one another, initially across broad divisions such as phyla and classes - homology of the tissue interactions that initiate the development of Meckel's cartilage in the lower jaw of amphibians, birds, and mammals (Goodwin et al. 1983), for example - but increasingly across smaller evolutionary gaps, to the point that pairs of species in the same genus (congeneric species) could be compared

- loss of the larval stage from one of a pair of congeneric sea urchins (Raff 1992), for example-

changes in the developmental processes in inbred strains of a single species of laboratory animal could be compared as experiments in evo-devo.

- changes in the timing (heterochrony) of the tissue interactions responsible for the induction of the lower jaw in three inbred strains of mice $(\mathrm{C} 57 \mathrm{BL}, \mathrm{C} 3 \mathrm{H} / \mathrm{He}$, CBA/J) by MacDonald and Hall (2001), for example-

to the present day when variation in individuals of a single species are revealing the mechanisms underlying the 
maintenance of natural variation in developmental processes upon which natural selection can act

- as in the correlation of genetic distance between individuals in relation to variation in the timing of developmental events in the pond snail, Radix balthica by Tills et al. (2011).

Evo-devo exploded as heterochrony was found everywhere. Along the way, heterochrony became such a pervasive term that it lost some of its explanatory power; any change in timing became heterochrony, whether evolutionarily relevant or not (Zelditch 2001, especially pp. vii-ix).

The next major impetus to evo-devo was not the resurrection of a previously known evolutionary developmental mechanisms but the discovery that all animals (subsequently shown for all plants and fungi too) share genes that contain a 180-bp sequence known as the homeobox and that these genes, known as homeobox, homeotic, or Hox genes, are responsible for determining that animals have an anterior and a posterior, a dorsal and a ventral side, and specific regions (often as repeated segments) along the body axishead at one end tail at the other, thorax in front of abdomen, wings on a specific pair of segments, and so forth (Lewis 1978; Gehring 1985, 1998; Averof 1997; Grenier et al. 1997; Carroll 2008).

"Master" genes, also known as developmental or regulatory genes, were discovered. One of the best understood of such genes is the paired-box protein gene known as Pax6 in vertebrates and as eyeless (ey) in Drosophila. As determined from its DNA sequence, orthologues of Pax-6 are present throughout the Animal Kingdom. As determined from functional studies, the role of Pax-6 in anteriorizing the embryo and in the formation of anterior sensory structures also is conserved across the Animal Kingdom. Although best known as the major gene controlling eye development, Pax- 6 functions in organisms that lack eyes, reflecting its ancient developmental role. Indeed, ey from fruit flies can initiate eyes in frogs and Pax-6 from frogs can initiate eyes in Drosophila (Dahl et al. 1997; Suga et al. 2010). Here is an astonishing and previously unthought-of genetic conservation across animals whose morphology varied enormously.

Heterochrony, homeotic genes, increasingly resolved relationships between organisms (phylogenetic trees), and an appreciation during the 1980s and 1990s of the importance of ecological and species interactions led evo-devo to the position where the aims of evo-devo could be stated as understanding:

- The origination and evolution of embryonic development;

- The role of modifications of developmental processes in the production of novel features;
- How the adaptive plasticity of development facilitates the origin and maintenance of complex life cycles with embryos, larvae, and adults; and

- How developing organisms interact with their ecological environment to facilitate evolutionary change (Hall 2000; West-Eberhard 2003).

Others had similar lists. Müller (2007a, b) and Collins et al. (2007) listed seven approaches and aims of evo-devo:

- The origin of developmental systems;

- The evolution of developmental systems;

- Modifications of timing and context of developmental processes;

- Environment-development interactions;

- Maintenance of phenotypic variation;

- Origin of phenotypic novelty; and

- Integration of genetics and epigenetic mechanisms.

Research programs in evo-devo are comparative and experimental (Hall 1999; Raff and Love 2004). Increasingly, they involve what Laubichler (2007) calls "evolutionary developmental genetics." In pursuit of their analysis of the integration of development, evolution, and ecology, Collins et al. (2007) analyzed three model systems - breeding of the domestic dog Canis familiaris, research on a sea anemone Nematostella vectensis, and research into horn development/ evolution in dung beetles in the genus Onthophagus - and the development/evolution of vertebrate limbs and mammalian teeth. In a very different approach, McCain (2010) identified trends in evo-devo between 1996 and 2008 by analyzing linkages between the literature in what she identified as three core journals of evo-devo [Evolution \& Development; Development, Genes \& Evolution; and the Journal of Experimental Zoology (Part B)]. Her analysis is worth a close examination, as is an earlier study in which the research of Conrad Waddington was used to trace the rise of evo-devo (McCain 2009).

Critical to our ability to answer these questions and evaluate these model systems are a sound basis to ensure that we are comparing the same organisms/processes/genes - the central biological concept of homology (Hall 1994, 2012) - and our ability to determine the direction of evolutionary change because of the development of robust phylogenetic trees of relationships (Valentine 2004; Erwin et al. 2011). We have the model systems and we have the methodology but still lack the required theory. In their analysis of the status of modeling in evo-devo, Collins et al. (2007) concluded that "these models are mostly diagrammatic and functional; very few analytical and predictive models exist within EvoDevo" (p. 373). In part, they see this deficiency residing in evo-devo's reliance on developmental genetics rather than evolutionary theory, a position that is slowly changing. 


\section{The Present}

Molecular genetics has revolutionized evo-devo over the past two decades. Integrating our expanding molecular understanding with mechanisms operating at the cell or other levels (tissues, organs, whole organism, organism-environment interactions; Box 1) has been and remains a major goal and a challenge for evo-devo. Essentially, it involves opening the black box between genotype and phenotype, taking out what is found in the box and how it fits together and then determining how to put the contents back in the box (Hall 1999, 2003a, b; West-Eberhard 2003; Carroll et al. 2005). One of the items found in the black box is known as epigenetics.

Box 1. A sample of evolutionary developmental mechanisms operating at various levels

\begin{tabular}{|c|c|}
\hline Gene & $\begin{array}{l}\text { Regulation, networks, interactions, genome size, } \\
\text { epigenetic processes (methylation, imprinting, } \\
\text { chromosome inactivation) }\end{array}$ \\
\hline Cell & $\begin{array}{l}\text { Division, migration, condensation, differentiation, } \\
\text { interaction, patterning, morphogenesis, embryonic } \\
\text { induction }\end{array}$ \\
\hline Tissue, organ & $\begin{array}{l}\text { Differentiation, specialization, embryonic inductions, } \\
\text { epithelial-mesenchymal interactions, growth }\end{array}$ \\
\hline Organism & $\begin{array}{l}\text { Ontogenetic re-patterning, genetic assimilation, } \\
\text { phenotypic plasticity, polymorphism, functional } \\
\text { morphology }\end{array}$ \\
\hline Environment & $\begin{array}{l}\text { Phenotypic responses to chemicals released by } \\
\text { predators, prey, and food supplies; temperature; } \\
\text { crowding }\end{array}$ \\
\hline
\end{tabular}

\section{Epigenetics}

Many of the controls on gene regulation and function are subsumed under the term "epigenetics," a term coined by the British geneticist and embryologist Conrad Waddington for the causal factors that control gene action during development (Waddington 1940; and see the papers in Hall and Laubichler 2009). Hall (1992) defined epigenetics as "the sum of the genetic and non-genetic factors acting upon cells to control selectively the gene expression that produces increasing phenotypic complexity during development" (1992, p. 89). To this, I would only add "and evolution" at the end.

Epigenetics is still used with this original meaning but has increasingly come to be applied at the molecular level for heritable changes to the DNA other than changes to the nucleotide bases. Such changes include methylation, imprinting, and regulation of chromatin-which have been known for some time (Biémont 2010; Hallgrímsson and Hall 2011; Moazed 2011; Molaro et al. 2011)-and regulation of genes by small RNA molecules, especially miRNAs (Kosik 2009; Hallgrímsson and Hall 2011). This now very well-characterized second inheritance system was appreciated in its infancy by John Maynard Smith, a leading twentieth century evolutionary theorist: "There is a second inheritance system - an epigenetic inheritance system - in addition to the system based on DNA sequence that links sexual generations (Maynard Smith 1989, p. 11).

The heritable aspect of epigenetics has shown us that organisms do not start their lives as naked nuclear DNA. They possess DNA in their mitochondria, epigenetic "marks" in their nuclear DNA, and they inherit mRNA and proteins that were produced under the control of their mother's DNA and deposited into the egg cytoplasm. Epigenetics provides another, but not the only other, means by which heritable information operates in organismal development. The ability to learn behaviors, interact with environments, and construct niches (Laland et al. 2008; Gissis and Jablonka 2011) are three further mechanisms introduced below.

\section{Integrated Mechanisms}

Integrated studies using molecular biology, molecular genetics, developmental biology, phylogenetics, paleontology, and molecular paleobiology are revealing previously unimagined information on how features change during evolution (Erwin and Wing 2000; Hall 2002; Wilkins 2002, 2007; Carroll et al. 2005; Peterson et al. 2007; Raff 2007; Erwin et al. 2011).

One instance is exemplified by the rise of paleobiology as a discipline that brought evolutionary theory back into paleontology and incorporated developmental, phylogenetic, and environmental approaches into a biological perspective of fossils. The journal Paleobiology celebrated its 25th anniversary in 2000 with a special issue, Deep Time: Paleobiology's Perspective, published as a supplement to volume 26. An edited volume of 26 essays by leading paleontologists and published in 2009 demonstrates the breadth and depth of insight achieved by paleobiology as "The Paleobiological Revolution" (Sepkoski and Ruse 2009).

We have long appreciated that development is responsible for introducing variation at the level of the individual (Darwin 1859; Thomson 1988; Hallgrímsson and Hall 2005; SalazarCiudad 2006; Fusco and Minelli 2010). Much of the research in evo-devo, however, has been conducted on features of organisms that characterize particular groups and whose evolutionary origin was a major departure (transition is the term often used for the change, novelty, or innovation for the character) from prior characters (Brylski and Hall 1988a, b; Hall and Kerney 2012). Important examples include feathers and the origin of birds/flight (Prum and Brush 2002; Xu et al. 
2011), flowers and the origin of land plants (Niklas 1997; Leliaert et al. 2011), wings and the origin of insects (Carroll et al. 1995; Abouheif and Wray 2002), and shells and the origin of turtles (Gilbert et al. 2001; Rieppel 2001; Willmore 2010). Indeed, some researchers see the major contribution of evodevo (and its major contribution to expanding the modern synthesis of evolution) as being to provide a theoretical basis from developmental biology for the origin of novelties (Müller and Wagner 1991; Müller 2007a, b Pigliucci and Müller 2010).

New groups of organisms, as represented by new classes or orders, can arise slowly through the gradual accumulation of new characters or can arise more rapidly through key innovations (the origination of wings or lungs, for example) or through coordinated changes in different characters as seen in the origin of lungs, middle ear ossicles, and the transformation of fins to limbs at the origin of the tetrapods (Thomson 1988; Shubin et al. 1997). This is how microevolutionary changes within species are linked to macroevolutionary changes, as reflected in levels of classification: "the careful analyses of the differences in pathways between organisms of known phylogenetic relationship" (Thomson 1988, p. 138).

The list of mechanisms summarized in Box 1 implies that evolutionary developmental mechanisms are not all found in the genes, although all have a genetic basis. This is because new mechanisms emerge as development proceeds. Evolutionary developmental mechanisms may be genetic, cellular, developmental, physiological, hormonal, or any combination of these. Embryonic development is hierarchical, with new properties and mechanisms emerging as development unfolds, each dependent on the stage/ processes preceding them. The single cell that is the fertilized egg cannot show any of the cell-to-cell interactions that characterize the multicellular embryo, some of which come about because cells take up new positions in the embryo through active migration. The recent elucidation of gene networks is providing the regulatory link between the genotype and cellular modules (Davidson 2006; Davidson and Erwin 2006; Wagner et al. 2007; Wilkins 2007). Embryonic inductions, tissue, organ, and functional interactions link cellular activity to the phenotype. The onset of embryonic movement ushers in a new type of process, which is interactions between developing tissues and organs such as bones and muscles (Box 1; and see Hall 1999, 2003a, b; Wilkins 2002; Hall and Olson 2003).

Some of the most striking information has come from the discovery that different morphological types of some single species (often referred to as morphs) arise following interactions with individuals of other species. These range from species that live in societies with different life history forms [chemical signaling between individuals determines the balance of workers and soldiers in ant colonies (Nijhout 1999); chemicals produced by predatory tadpole shrimp induce the formation of a protective helmet and enlargement of the head in the water shrimp Daphnia (Petrusek et al. 2009)]; the density of tadpoles and/or the amount of food promoting the development of large cannibalistic tadpoles in such species as the New Mexico spadefoot toad Scaphiopus multiplicatus (Pfennig 1992; Ledón-Rettig and Pfenning 2011); moth larvae-mimicking leaves of catkins in response to seasonal levels of tannin produced by oak trees when either catkins or leaves are on the trees (Greene 1989, 1999); and interactions of bacterial viral and eukaryotic species in the human gut with one another and the role of this microbiota in maintaining the health of their human hosts (Clemente et al. 2012).

\section{The Future}

Of course, it is impossible to tell what the future of evodevo will be or what evo-devo will bring to the future. Nevertheless, given the past dramatic history of links between development and evolution, it is interesting to speculate on the future.

It could be business as usual, with evo-devo continuing to inform us of how changes in development relate to changes in evolution. Or evo-devo may change.

\section{Evo-devo Plus Endless Prefixes/Suffixes}

The past decade has seen the addition of modifiers to evodevo to reflect its embracing of other fields. Thus:

- Eco-evo-devo brings ecology into evo-devo (Hall 2003a; Gilbert and Apel 2008).

- Evo-devo-niche construction links development to the evolutionary role of organisms constructing essential elements of their niche such as nests or tunnels (Laland et al. 2008).

- Behav-evo-devo is the use of evolutionary developmental mechanisms to explain the origins of behaviors, learning, and language (Lickliter 2007; Bertossa 2011; Hoang et al. 2011; Hall 2012).

- Evo-devo-medicine is the application of evo-devo to medical practice (Gluckman et al. 2009).

The future of evo-devo may be a continuation of this trend: evo-devo-physiology; evo-devo-life history evolution.

\section{Devo-Evo}

Or it could be that evo-devo will be replaced by what has been called developmental evolution or devel-evol (Hall 2000; Wagner 2000). 
What is the difference between evo-devo and devo-evo? Evo-devo seeks to situate development within the study of evolution (Carroll 2008). Devo-evo seeks to generate a new theory of evolution based in development. Gunter Wagner and his colleagues (Wagner 2000; Wagner et al. 2000; Wagner and Larsson 2003), for example, maintain that understanding (1) the origin of innovations (novelties), (2) why development is constrained along particular paths, and (3) how new properties emerge in evolution requires an approach that is fundamentally evolutionary (devo-evo) rather than developmental (evo-devo).

Devo-evo would provide a new theory of the origin of novel structures and behaviors with evolution based on population genetics continuing to explain variation in existing phenotypes and different theories to explain the evolution of the new and the maintenance of the old (Hallgrímsson and Hall 2005, 2011). Ken Weiss emphasized this in a discussion of the importance of niche construction and behavior-driven evolution when he concluded that "local divergence can be achieved by behavioral sorting by which organisms find or modify local niches according to their abilities, but this need not involve fitness differences nor even be based on genetic inheritance" (Weiss 2004, p. 203).

\section{Evo- $-\operatorname{devo}=$ Evo}

Or, it could be, as Scott Gilbert mused, "that sooner or later, the term 'evo-devo' will be abandoned, because at that time it will have become synonymous with 'evolutionary biology" (Gilbert 2009, p. 332). The Modern Synthesis forged in the 1930s and 1940s will become the "Expanded Modern Synthesis" or the "Extended Synthesis" of the twenty-first century. Although there were calls in the past for the replacement of the modern synthesis, the expectation now is an expanded synthesis that incorporates development (Müller 2007a, b; Pigliucci and Müller 2010). Sommer (2009), who evaluated the various likely fates of evo-devo, demonstrated that "a synthesis of evo-devo with population genetics and evolutionary ecology is needed to meet future challenges" (p. 416), those challenges being to understand phenotypic change and novelty (his call for researchers to choose a limited number of model organisms goes against a major trend in evo-devo, which is to expand the numbers of organisms under investigation).

\section{Unification}

An expanded synthesis will be more than the modern synthesis plus evo-devo.

Laubichler (2010) argues that "the revolutionary nature of evo-devo lies precisely in its return to a more inclusive conception of phenotypic evolution, one that more closely resembles the conceptual framework of Darwin and the first few generations of evolutionists than the more narrowly focused interpretation of the Modern Synthesis" (p. 199). Laubichler is referring to the separation of the study of heredity, development, and evolution early in the twentieth century (Allen 1975; Laubichler and Maienschein 2007; Deichman 2011) and the need to reunify these three before a full account of development, evolution, or evo-devo can be given. Biology was integrated in the late nineteenth century. Evo-devo will be at center stage when we forge the integrated biology of the twenty-first century.

Conceptual unification will require much more than the addition of more and more suffixes and prefixes until all of biology is ensnared by evo-devo. As Laubichler (2007) points out, "any future synthesis of evo-devo will be conceptual rather than simply data driven...[and allow] the integration of developmental mechanisms into evolutionary explanations at a higher level of resolution than the current ideas about regulatory evolution and the evolution of the genetic toolkit suggest" (pp. 343, 359). At the very least, unification will involve molecular genetics, development, paleontology, systematics, the nature of heredity, and the role of ecology and the environment.

Experience from the past teaches us that unification could arise from the development of new techniques and methods, as occurred with the ability to identify biological species, decipher the genetic code in DNA, sequence genomes, and create phylogenetic trees. Experience also teaches us that unification may (is more likely to?) require unthought-of and perhaps revolutionary concepts and/or new ways to integrate signaling mechanisms operating at different levels (genes, cells, organs, organisms-environment). The gene regulatory networks discussed above provide such a conceptual and integrative advance at the level of gene action, but so far, they are not sufficient to link the activity of genes to the activities of cells. The phenotypic plasticity that links environment to phenotypic response is integrative at the level of environment-organism, but not at the level of genes-cells. We have traveled an enormously long way, but have an even longer uncharted road ahead.

Acknowledgments Research in my laboratory is supported by the Natural Sciences and Engineering Research Council (NSERC) of Canada (grant A5056). I thank all past laboratory colleagues-students, postdoctoral fellows, sabbaticants, and collaborators-for discussions from which I have benefited enormously over the past 44 years. Jane Maienschein and an anonymous referee provided important comments on the manuscript.

\section{References}

Abouheif E, Wray G. Evolution of the gene network underlying wing polyphenism in ants. Science. 2002;297:249-52.

Allen G. Life science in the twentieth century. New York: Wiley; 1975. 
Arthur W. A theory of the evolution of development. Chichester: Wiley; 1988.

Averof M. Arthropod evolution: same Hox genes, different body plans. Curr Biol. 1997;7:R634-6.

Balfour FM. A preliminary account of the development of the elasmobranch fishes. Q J Microsc Sci. 1874;14:323-64.

Bateson W. Evolutionary faith and modern doubts. Science. 1922;55:53-61.

Berrill NJ. Biology in action: a beginning college textbook. New York: Dodd, Mead \& Co.; 1966.

Bertossa RC. Morphology and behaviour: functional links in development and evolution. Philos Trans R Soc B. 2011;366:2056-68.

Biémont C. From genotype to phenotype. What do epigenetics and epigenomics tell us? Heredity. 2010;105:1-3.

Bonner JT. Evolution and development. Report of the Dahlem Workshop on Evolution and Development, Berlin 1981, May 10-15. Life Sciences Research Report 22. Berlin: Springer; 1982.

Bowler PJ. Life's splendid drama. Evolutionary biology and the reconstruction of life's ancestry 1860-1940. Chicago: The University of Chicago Press; 1996.

Brylski P, Hall BK. Ontogeny of a macroevolutionary phenotype: the external cheek pouches of geomyoid rodents. Evolution. 1988a;42:391-5.

Brylski P, Hall BK. Epithelial behaviour and threshold effects in the development of external and internal cheek pouches in rodents. Zool Syst Evolutionsforsch. 1988b;26:144-54.

Calow P. Life cycles: an evolutionary approach to the physiology of reproduction, development and ageing. London: Wiley; 1978.

Calow P. Evolutionary principles. Blackie: Glasgow and London; 1983.

Carroll SB. Evo-devo and an expanding evolutionary synthesis: a genetic theory of morphological evolution. Cell. 2008;134:25-36.

Carroll SB, Weatherbee SD, Langeland JA. Homeotic genes and the regulation and evolution of insect wing number. Nature. 1995;375:58-61.

Carroll SB, Grenier JK, Weatherbee SD. From DNA to diversity. Molecular genetics and the evolution of animal design. 2nd ed. Malden: Blackwell Science; 2005.

Clemente JC, Ursell LK, Palfrey LW, Knight B. The impact of the gut microbiota on human health: an integrative view. Cell. 2012; 148:1258-70

Collins JP, Gilbert S, Laubichler MD, Müller GB. Modeling in EvoDevo: how to integrate development, evolution, and ecology. In: Laubichler MD, editor. Roots of theoretical biology: the Prater Vivarium centenary. Cambridge: MIT Press; 2007. p. 355-78

Dahl E, Koseki H, Balling R. Pax genes and organogenesis. BioEssays. 1997;19:755-65.

Darwin CR. The origin of species by means of natural selection. London: John Murray; 1859.

Davidson EH. The regulatory genome: gene regulatory networks in development and evolution. San Diego: Academic; 2006.

Davidson EH, Erwin DH. Gene regulatory networks and the evolution of animal body plans. Science. 2006;311:796-800.

de Beer GR. Embryos and evolution. Oxford: Clarendon; 1930.

Deichman U. Early 20th-century research at the interface of genetics, development, and evolution: reflections on progress and dead ends. Dev Biol. 2011;347:3-12.

Dobzhansky Th. Genetics and the origin of species. New York: Columbia University Press; 1937.

Erwin DH, Wing SL. Deep time: paleobiology's perspective. Paleobiology (Suppl). 2000;26(4):1-371.

Erwin DH, Laflamme M, Tweedt SM, Sperling EA, Pisani D, Peterson KJ. The Cambrian conundrum: early divergence and later ecological success in the early history of animals. Science. 2011;334:1091-7.

Fusco G, Minelli A. Phenotypic plasticity in development and evolution: facts and concepts. Philos Trans R Soc B. 2010;365:547-56.
Gehring WJ. The homeobox: a key to the understanding of development? Cell. 1985;40:3-5.

Gehring WJ. Master control genes in development and evolution: the homeobox story. New Haven: Yale University Press; 1998.

Gilbert SF. 2009 BIO. Evol Dev. 2009;11:331-2.

Gilbert SF, Apel D. Ecological developmental biology: integrating epigenetics, medicine, and evolution. Sunderland: Sinauer Associates; 2008

Gilbert SF, Loredo GA, Brukman A, Burke AC. Morphogenesis of the turtle shell: the development of a novel structure in tetrapod evolution. Evol Dev. 2001;3:47-58.

Gissis SB, Jablonka E. Transformations of Lamarckism: from subtle fluids to molecular biology. Cambridge: MIT Press; 2011.

Gluckman P, Beedle A, Hanson M. Principles of evolutionary medicine. Oxford: Oxford University Press; 2009.

Goldschmidt R. A preliminary report on some genetic experiments concerning evolution. Am Nat. 1918;52:28-50.

Goodwin BC, Holder NJ, Wylie CC, editors. Development and evolution. Cambridge: Cambridge University Press; 1983.

Gould SJ. Ontogeny and phylogeny. Cambridge: The Belknap Press of Harvard University Press; 1977.

Greene E. A diet-induced developmental polymorphism in a caterpillar. Science. 1989;243:643-66.

Greene E. Phenotypic variation in larval development and evolution: polymorphism, polyphenism, and developmental reaction norms. In: Hall BK, Wake MH, editors. The origin and evolution of larval form. San Diego: Academic; 1999. p. 379-410.

Grenier JK, Garber TL, Warren R, Whitington PM, Carroll SB. Evolution of the entire arthropod Hox gene set predated the origin and radiation of the onychophoran/arthropod clade. Curr Biol. 1997;7:547-53.

Haeckel E. Generelle morphologie der organismen: Allgemeine grundzüge der organischen formen-wissenschaft, mechanisch begründet durch die von Charles Darwin reformite descendenztheorie (2 volumes). Berlin: Georg Reimer; 1866.

Hall BK. Evolutionary developmental biology. London: Chapman and Hall; 1992.

Hall BK. Homology: the hierarchical basis of comparative biology. San Diego: Academic; 1994.

Hall BK. Evolutionary developmental biology. 2nd ed. Dordrecht: Kluwer Academic; 1999.

Hall BK. Evo-devo or devo-evo-does it matter? Evol Dev. 2000;2:177-88.

Hall BK. John Samuel Budgett (1872-1904): in pursuit of Polypterus. BioScience. 2001;51:399-407.

Hall BK. Palaeontology and evolutionary developmental biology: a science of the 19 th and 21 st centuries. Palaeontology. 2002:45:647-69.

Hall BK. Evolution as the control of development by ecology. In: Hall BK, Pearson R, Müller GB, editors. Environment, evolution and development: towards a synthesis. Cambridge: MIT Press; 2003a. p. ix-xxiii.

Hall BK. Unlocking the black box between genotype and phenotype: cells and cell condensations as morphogenetic (modular) units. Biol Philos. 2003b;18:219-27.

Hall BK. Homology, homoplasy, novelty and behavior. Dev Psychobiol. 2012 (in press).

Hall BK, Kerney R. Levels of biological organization and the origin of novelty. J Exp Zool (Mol Dev Evol). 2012;314B. doi:10.1002/ jez.b.21425.

Hall K, Olson WM (eds). Keywords and concepts in evolutionary developmental biology. Cambridge, MA: Harvard University Press; 2003

Hall BK, Laubichler MD, (eds). Conrad Hal Waddington, theoretical biology, and evo-devo. Biol. Theory. 2009;3(3):185-289. 
Hallgrîmsson B, Hall BK, editors. Epigenetics: linking genotype and phenotype in development and evolution. Berkeley: University of California Press; 2011.

Hallgrímsson B, Hall BK (eds). Variation: a central concept in biology .New York: Elsevier/Academic Press; 2005

Hoang T-H, McKay RI, Essam D, Hoai NX. On synergistic interactions between evolution, development and layered learning. IEEE Trans Evol Comput. 2011;15:287-311.

Huxley JS. Evolution: the modern synthesis. London: Allen and Unwin; 1942.

Kosik KS. MicroRNAs tell an evo-devo story. Nat Rev Neurosci. 2009;10:754-9.

Laland KN, Odling-Smee J, Gilbert SF. EvoDevo and niche construction: building bridges. J Exp Zool (Mol Dev Evol). 2008;310B:54966.

Laubichler MD. Evolutionary developmental biology. In: Hull DL, Ruse M, editors. The Cambridge companion to the philosophy of biology. Cambridge: Cambridge University Press; 2007. p. 342-60.

Laubichler MD. Evolutionary developmental biology offers a significant challenge to the neo-Darwinian paradigm. In: Ayala FJ, Arp $\mathrm{R}$, editors. Contemporary debates in philosophy of biology. Malden: Wiley-Blackwell; 2010. p. 199-212.

Laubichler MD, Maienschein J, editors. From Embryology to evodevo: a history of developmental evolution. Cambridge: MIT Press; 2007.

Laubichler MD, Wagner GP. Introduction to the papers of the 2001 Kowalevsky Medal winner symposium. J Exp Zool (Mol Dev Evol). 2004;302B:1-4.

Ledón-Rettig CC, Pfenning DW. Emerging model systems in ecoevo-devo: the environmentally responsive spadefoot toad. Evol Dev. 2011;13:391-400.

Leliaert F, Verbruggen H, Zechman FW. Into the deep: new discoveries at the base of the green plant phylogeny. BioEssays. 2011;33:683-92.

Lewis EB. A gene complex controlling segmentation in Drosophila. Nature. 1978;276:565-70.

Lickliter R. The dynamics of development and evolution: insights from behavioral embryology. Dev Psychobiol. 2007;49:749-57.

MacDonald ME, Hall BK. Altered timing of the extracellular-matrixmediated epithelial-mesenchymal interaction that initiates mandibular skeletogenesis in three inbred strains of mice: development, heterochrony, and evolutionary change in morphology. $\mathrm{J}$ Exp Zool. 2001;291:258-73.

Macleod R. Embryology and empire. In: Macleod R, Rehbock PF, editors. Darwin's laboratory. Evolutionary theory and natural history in the Pacific. Honolulu: University of Hawaii Press; 1994. p. $140-65$.

Maynard Smith J. Weismann and modern biology. In: Harvey PH, Partridge L, editors. Oxford surveys in evolutionary biology, vol. 6. Oxford: Oxford University Press; 1989. p. 1-12.

Mayr E. The growth of biological thought. Diversity, evolution, and inheritance. Cambridge: The Belknap Press of Harvard University Press; 1982.

Mayr E. The establishment of evolutionary biology as a discrete biological discipline. BioEssays. 1997;19:263-6.

McCain KW. Using tricitation to dissect the citation image: Conrad Hal Waddington and the rise of evolutionary developmental biology. J Am Soc Inf Sci Technol. 2009;60:1301-19.

McCain KW. Core journal literatures and persistent research themes in an emerging interdisciplinary field: exploring the literature of evolutionary development biology. J Informet. 2010;4:15765 .

Moazed D. Mechanisms for the inheritance of chromatin states. Cell. $2011 ; 146: 510-7$.
Molaro A, Hodges E, Fang F, Song Q, McCombie WR, Hannon GJ. Sperm methylation profiles reveal features of epigenetic inheritance and evolution in primates. Cell. 2011;146:1029-41.

Müller F. Für Darwin. Leipzig: Engelman; 1864 (Translated by W. S. Dallas as Facts and Arguments for Darwin, London: John Murray, 1869).

Müller GB. Six memos for EvoDevo. In: Laubichler MD, Maienschein J, editors. From Embryology to evo-devo: a history of developmental evolution. Cambridge: MIT Press; 2007a. p. 499-524.

Müller GB. Evo-devo" extending the evolutionary synthesis. Nat Rev Genet. 2007b;8:943-9.

Müller GB, Wagner GP. Novelty in evolution: restructuring the concept. Annu Rev Ecol Syst. 1991;22:229-56.

Nijhout HF. Hormonal control in larval development and evolutioninsects. In: Hall BK, Wake MH, editors. The origin and evolution of larval form. San Diego: Academic; 1999. p. 217-54.

Niklas KJ. The evolutionary biology of plants. Chicago: The University of Chicago Press; 1997.

Olsson L, Hoßfeld U, Breidbach O. Preface. Between Ernst Haeckel and the homeobox: the role of developmental biology in evolution. Theory Biosci. 2009;128:1-5.

Peterson KJ, Summons RE, Donoghue PCJ. Molecular paleobiology. Palaeontology. 2007;50:775-809.

Petrusek A, Tollrian R, Schwenk K, Haas A, Laforsch C. A "crown of thorns" is an inducible defense that protects Daphnia against an ancient predator. Proc Natl Acad Sci USA. 2009; 106:2248-52.

Pfennig DW. Polyphenism in spadefoot toad tadpoles as a locally adjusted evolutionarily stable strategy. Evolution. 1992;46:1408-20.

Pigliucci M, Müller GB, editors. Evolution - the extended synthesis. Cambridge: The MIT Press; 2010.

Prum RO, Brush AH. The evolutionary origin of diversification of feathers. Q Rev Biol. 2002;77:261-95.

Raff RA. Direct-developing sea urchins and the evolutionary reorganization of early development. BioEssays. 1992;14:211-8.

Raff RA. Written in stone: fossils, genes and evo-devo. Nat Rev Genet. 2007;8:911-20.

Raff RA, Love AC. Kowalevsky, comparative evolutionary embryology, and the intellectual lineage of evo-devo. J Exp Zool (Mol Dev Evol). 2004;302B:19-34.

Rieppel O. Turtles as hopeful monsters. BioEssays. 2001;23:987-91.

Salazar-Ciudad I. Developmental constraints vs. variational properties: how pattern formation can help to understand evolution and development. J Exp Zool (Mol Dev Evol). 2006; 306B:107-25.

Sepkoski D, Ruse M. (eds). The paleobiological revolution: essays on the growth of modern paleontology. Chicago: The University of Chicago Press; 2009.

Shubin N, Tabin C, Carroll S. Fossils, genes, and the evolution of animal limbs. Nature. 1997;388:639-48.

Sommer RJ. The future of evo-devo: model systems and evolutionary theory. Nat Rev Genet. 2009;10:416-22.

Suga H, Tschopp P, Graziussi DF, Stierwald M, Schmid V, Gehring WJ. Flexibly deployed Pax genes in eye development at the early evolution of animals demonstrated by studies on a hydrozoan jellyfish. Proc Natl Acad Sci USA. 2010;107:14263-8.

Thomson KS. Morphogenesis and evolution. Oxford: Oxford University Press; 1988

Tills O, Rundle SD, Salinger M, Haun T, Pfenninger M, Spicer JI. A genetic basis for intraspecific differences in developmental timing? Evol Dev. 2011;13:542-8.

Valentine JW. On the origin of phyla. Chicago: The university of Chicago Press; 2004.

Waddington $\mathrm{CH}$. Organizers and genes. Cambridge: Cambridge University Press; 1940. 
Wagner GP. What is the promise of developmental evolution? Part I: Why is developmental biology necessary to explain evolutionary innovations? J Exp Zool (Mol Dev Evol). 2000;288:95-8.

Wagner GP, Larsson HCE. What is the promise of developmental evolution? III. The crucible of developmental evolution. J Exp Zool (Mol Dev Evol). 2003;300B:1-4.

Wagner GP, Chiu C-H, Laubichler M. Developmental evolution as a mechanistic science: the inference from developmental mechanisms to evolutionary processes. Am Zool. 2000;40:819-31.

Wagner GP, Pavlicev M, Cheverud JM. The road to modularity. Nat Rev Genet. 2007;8:921-31.

Weiss KM. Thomas Henry Huxley (1825-1895) puts us in our place. J Exp Zool (Mol Dev Evol). 2004;302B:196-206.
West-Eberhard MJ. Developmental plasticity and evolution. Oxford: Oxford University Press; 2003.

Wilkins AS. The evolution of developmental pathways. Sunderland: Sinauer Associates; 2002.

Wilkins AS. Between "design" and "bricolage": genetic networks, levels of selection, and adaptive evolution. Proc Natl Acad Sci USA. 2007;104:8590-6.

Willmore KE. Development influences evolution. Am Sci. 2010;98:220-7.

$\mathrm{Xu}$ X, You H, Du K, Han F. An Archaeopteryx-like theropod from China and the origin of Avialae. Nature. 2011;475: 465-70.

Zelditch M. Beyond heterochrony: the evolution of development. New York: Wiley; 2001. 